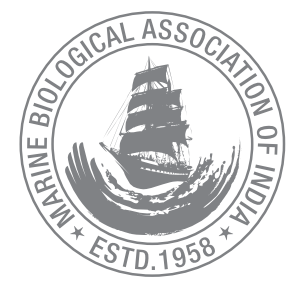

\title{
Effect of pediveliger densities and cultch materials on spat settlement of black lip pearl oyster Pinctada margaritifera (Linnaeus, 1758) in hatchery
}

\author{
C. Linoy Libini* ${ }^{*}$ C.C. Manjumol, K.A. Albert Idu, V. Kripa' and K.S. Mohamed ${ }^{1}$ \\ Blacklip Pearl Oyster Laboratory of CMFRI, Fisheries Training Centre, Marine Hill, Port Blair 744101, Andaman and \\ Nicobar Islands. Tel: 03192-230367 \\ ${ }^{1}$ Central Marine Fisheries Research Institute, P.B. No. 1603, Kochi - 682018, India.
}

*Correspondence e-mail: linoylibini@gmail.com

Received: 28 Jan 2013, Accepted: 15 May 2013, Published: 30 May 2013

Original Article

\begin{abstract}
The settlement of hatchery produced spat of the blacklip pearl oyster Pinctada margaritifera was investigated with respect to time of introduction of settlers, type of cultch material and the larval (pediveliger) densities. The study clearly indicated that the ideal time for deployment of spat collectors in the hatchery is when the pediveligers are beginning to appear in the larval rearing tank. In similar larval stocking densities, the settlement was more on the spat collectors which were deployed when the larvae had not metamorphosed to spat. Six different types of cultch materials were tested for their efficiency in three larval densities. The study showed that better spat collection of $P$. margaritifera can be achieved in hatcheries by providing darkness, and employing dark coloured, rough-surfaced, corrugated and conditioned spat collectors such as the garden shade spiral at higher larval densities of $1.0 \mathrm{nos} / \mathrm{ml}$.
\end{abstract}

Keywords: Pinctada margaritifera, hatchery, larval stocking density, collectors, spat settlement.

\section{Introduction}

In the cultured pearl industry, implantable size adult (mother) oysters are sourced either from naturally collected spats or from farm grown hatchery spats. In India, particularly in Andaman and Nicobar Islands, the black lip pearl oyster, Pinctada margaritifera farming is yet to be commercialised due to limited pearl oyster resources in the natural beds. The hatchery technology for these oysters has been developed in mainland India (Alagarswami et al., 1989) and in the Andaman and Nicobar Islands (Mohamed et al., 2010). This has opened up new opportunities for initiating black pearl farming and pearl production in these islands.

In pearl oyster hatcheries in India, spats are usually settled down to bottom of larval rearing tank and reared until they reach transplantable size. These settled spat are removed with sponge or soft brush and transplanted to the farm (Alagarswami et al., 1987). Such handling can damage the byssus and internal organs and result in high mortality rate of spats. It also leads to energy loss in the animal due to the time taken for regeneration and find a new surface for resettlement. This can be solved by deploying necessary spat collectors which will provide appropriate substrate for spats to settle. Such practices are in vogue in pearl oyster hatcheries in the south Pacific (Braley and Munro, 1997). The materials used as spat collectors should be cheap, durable and locally available (Vakily, 1989). In collection of spats from the wild, improper timing of spat collector deployment can result in significant 'by-catch' of unwanted species (Crossland, 1957). Quite a lot of materials have been tried as spat collectors for $P$. margaritifera spats from the wild in different regions 
(Passfield, 1989; Coeroli et al., 1984; Crossland, 1957; Rahma and Newkrik, 1987; Friedman et al., 1998; Haws and Ellis, 2000). The timing of spat collector deployment is critical and must be decided with the availability of settling larvae during phase of metamorphosis (Southgate, 2008).

In the blacklip pearl oyster hatchery at Port Blair, spats were settled inside tank surfaces which usually resulted in prolonged spat settlement, besides poor spat harvests (Mohamed et al., 2010). The present study was conducted to identify the right time for deploying spat collectors in larval rearing tanks, preference of larvae to different materials and influence of various stocking densities on settlement of larvae in the hatchery. The outcome of the study is expected to improve the efficiency of blacklip pearl oyster spat settlement and rearing in hatcheries.

\section{Material and methods}

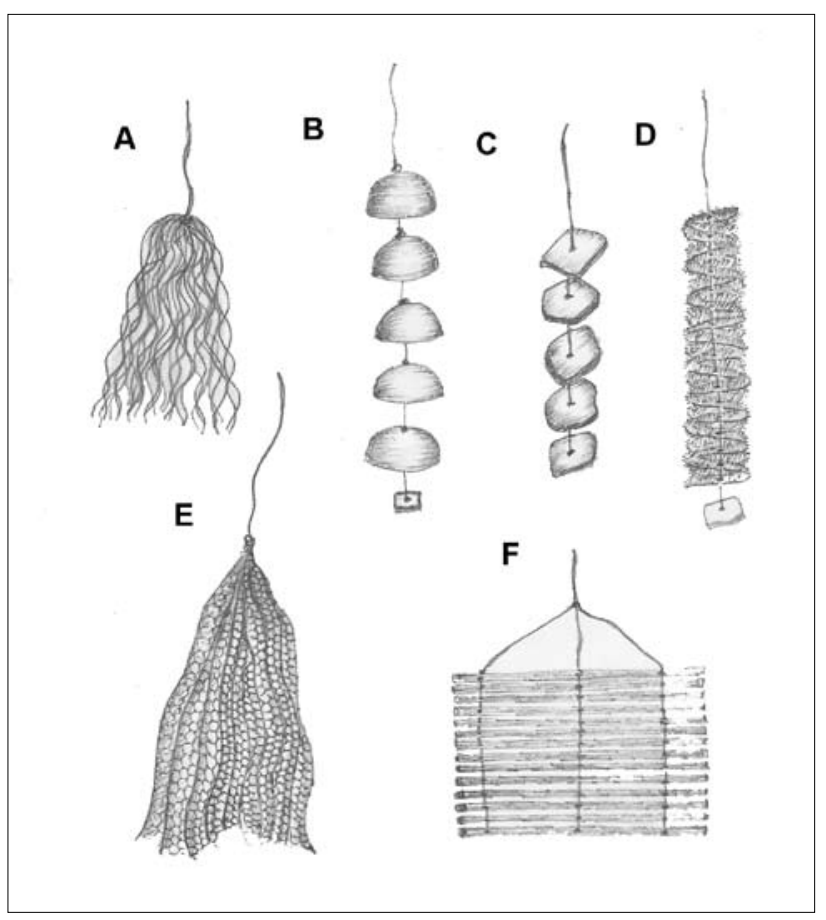

Fig.1 Types of spat collectors selected for the experiment - frilled nylon rope $(A)$; coconut shell ren (B); clay tile ren $(C)$; garden shade spiral (D); frilled cod-end net (E) and bamboo matting (F).
Six types of spat collection materials were selected for the experiment (Fig 1) of which three were of natural materials (coconut shell ren; clay tile ren and bamboo matting) and three of synthetic materials (garden shade spiral; frilled codend net and frilled nylon rope). Each collector was measured to calculate the surface area available for spat settlement separately. The detailed descriptions of cultch material and surface area available are given in Table 1. All the collectors were conditioned for leaching-out potential toxins and for biofilm formation by soaking in a tank with seawater for 4 days prior to use. In the hatchery, larval rearing was carried out in black rectangular FRP tanks@800 I of dimension $200 x$ $100 \times 50 \mathrm{~cm}$. The tanks were covered with thick black cloth to prevent entry of light and dust into the tank and no aeration was provided. The seawater was filtered using sand, cartridge (range 10 to $0.3 \mu$ ) and UV lamps prior to use. The study was conducted with four treatments (E1 to E4) with two different larval stages (E1 and E2) and with three different pediveliger densities (E2, E3 and E4) (Table 2). Microalgal feed (Pavalova salina and Chaetoceros calcitrans; ratio 1:1) was provided to the larvae at the rate of 30,000 cells $/ \mathrm{ml}$.

All treatments were carried out in three replicates. Spat collectors were randomly hung and deployed from horizontal nylon lines with equal intervals in larval rearing tanks. In all the treatments, spats were allowed to settle and grow further. Spats grew to an average size of $4 \mathrm{~mm}$ within 48 days of culture (DOC). Collectors were removed and observed on day 48 after deployment of collectors. Total number and density of spats attached on each spat collector in all the treatments were observed and recorded separately. Two-way ANOVA was carried out to test for significant differences in spat settlement counts with respect to time of introduction of the settlers and also the effect of different substrate materials (E1 versus E2, both having same spat density). Additionally another two-way ANOVA was done to test the effect of spat density and substrate material (E2, E3 and E4). When significant differences were seen, a post-hoc Duncan Multiple Range Test (DMRT) was applied to compare the means at 5\% level using SPSS software (version 16).

Table 1. Details of collector materials (cultch substrates) used, colour and total surface area available for spat settlement

\begin{tabular}{llll}
\hline Type of Collector/ cultch substrate & Specification & Total surface area & Colour \\
\hline Garden shade spiral & $900 \times 10 \mathrm{~cm}$ & $18000 \mathrm{~cm}^{2}$ & Black \\
\hline Coconut shell ren & $11 \mathrm{~cm} \mathrm{dia}(5$ piece/ren) & $1036.2 \mathrm{~cm}^{2}$ & Brown \\
\hline Frilled cod-end net & $30 \times 30 \mathrm{~cm}$ & $1800 \mathrm{~cm}^{2}$ & Blue \\
\hline Tile ren & $5 \times 5 \times 2.5 \mathrm{~cm}(5$ piece/ren$)$ & $500 \mathrm{~cm}^{2}$ & Red \\
\hline Frilled rope & $30 \times 1.2 \mathrm{~cm}(4$ piece) & $288 \mathrm{~cm}^{2}$ & Yellow \\
\hline Bamboo matting & $60 \times 46 \mathrm{~cm}$ & $5520 \mathrm{~cm}^{2}$ & Green \\
\hline
\end{tabular}


Table 2. Details of various experimental treatments used to study Pinctada margaritifera spat settlement in hatchery.

\begin{tabular}{llll}
\hline Treatment & Larval stage used & Larval density & Spat collectors used (Fig.1) \\
\hline E1 & After spat formation & $0.2 / \mathrm{ml}$ & A-F types \\
\hline E2 & After pediveliger formation & $0.2 / \mathrm{ml}$ & A-F types \\
\hline E3 & After pediveliger formation & $0.6 / \mathrm{ml}$ & A-F types \\
\hline E4 & After pediveliger formation & $1.0 / \mathrm{ml}$ & A-F types \\
\hline
\end{tabular}

\section{Results and discussion}

Comparison of the results of treatments E1 and E2 showed that spat settlement was significantly $(P<0.01)$ higher when the spat settlers were introduced at the pediveliger stage (Day 22) rather than after metamorphosis to spat (Fig.2). The spat counts were almost doubled when settlers were introduced at pediveliger stage in the case of cultch substrates such as garden shade spiral, coconut shell ren, frilled cod-end net and tile ren. In frilled rope treatment the difference between E1 and E2 was small, whereas in the case of bamboo matting treatment, the introduction of settlers after spat formation proved to be better (Fig.2). DMRT revealed 4 different mean subsets, with garden shade spiral being significantly different from all other cultch substrates. Identification of suitable time

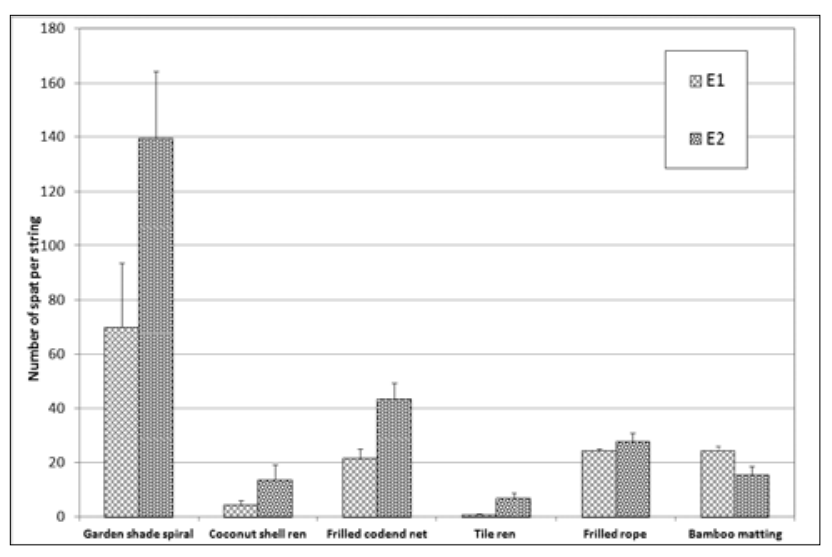

Fig.2 Comparison of number of spat settled after 48 DOC when settlers were introduced after spat formation (E1) and during pediveliger stage (E2). Vertical bars indicate standard deviation.

for deployment of spat settlers is a prime factor influencing the success of a hatchery operation for any pearl oyster species. In the present study, the spat collectors deployed during the pediveliger stage had significantly higher spat settlement than that of the collectors deployed after the pediveligers had started metamorphosing to spat. In this transitional phase, they are in search of an ideal surface to settle down (Alagarswami et al., 1987). This is because of the formation of functional foot during the pediveliger stage and adapted to a benthic crawling life after transformation from a pelagic swimming eyespot larvae. Most other workers have not

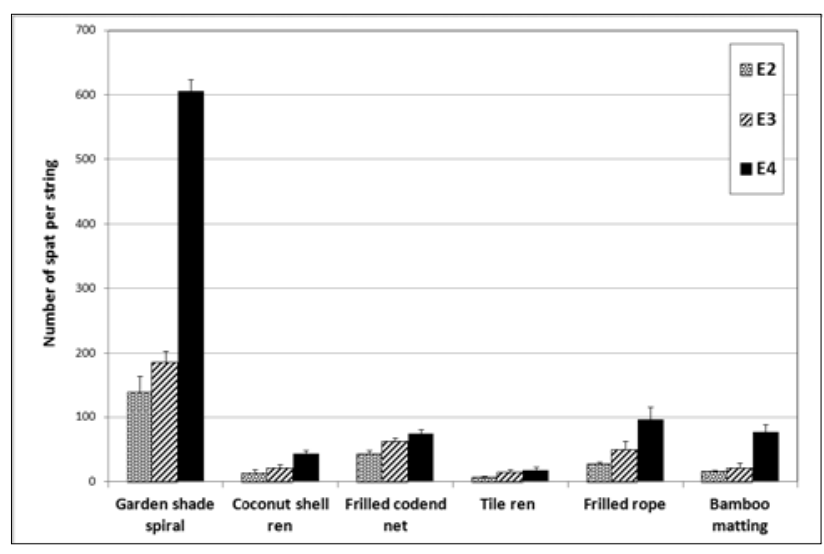

Fig.3 Comparison of number of spat settled after 48 DOC using different cultch substrates under different pediveliger densities, 0.2 pediveliger/ml (E2); 0.6 pediveliger/ml (E3) and 1.0 pediveliger/ml (E4). Vertical bars indicate standard deviation.

tested the effect of timing, thereby missing the correct time for deployment of spat collectors in the hatchery tanks and ends up in spats settling on tank surfaces. Collection of the spats from tank surfaces will become a tiresome job and can also cause injury to them.

Among the different cultch materials tested, high percentage of settlement was observed in the garden shade spirals than that of any other cultch materials (Fig.3). Low settlement was observed on tile ren and coconut shell ren respectively. Moderate settlements were recorded on frilled cod-end net, frilled rope and bamboo mat. ANOVA (Table 3) showed that the differences in spat settlement in different cultch substrates were highly significant $(P<0.01)$. DMRT also confirmed that the means of the different treatments were significantly different with the garden shade spiral forming a separate subset. The influence of stocking density of pediveligers on settlement of spat on settlers was also marked (Fig.3). As the stocking density increased from 0.2 to 0.6 and 1.0 pediveliger/ $\mathrm{ml}$, the settlement rate doubled in most treatments, and it was tripled in the case of garden shade spiral. The garden shade spiral out performed other treatments by the order of 6 -times. ANOVA (Table 3 ) indicated that the treatments results were significantly different $(P<0.01)$ with respect to pediveliger density and DMRT showed that the means of all 3 densities were significantly different $(P<0.05)$. ANOVA also 
Table 3. Results of Two-way ANOVA tests for comparison of time of introduction of spat collectors, type of spat collectors and pediveliger densities. Output from SPSS $v 16$.

\begin{tabular}{|c|c|c|c|c|c|c|}
\hline Test & Source & Type III Sum of Squares & $\mathrm{df}$ & Mean Square & F value & Significance \\
\hline \multirow{7}{*}{ 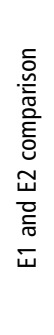 } & Corrected Model & 49239.222 & 11 & 4476.293 & 42.307 & $.000^{*}$ \\
\hline & Time & 2567.111 & 1 & 2567.111 & 24.263 & $.000^{*}$ \\
\hline & Type & 40910.222 & 5 & 8182.044 & 77.331 & $.000^{*}$ \\
\hline & Time * Type & 5761.889 & 5 & 1152.378 & 10.891 & $.000^{*}$ \\
\hline & Error & 2539.333 & 24 & 105.806 & & \\
\hline & Total & 90064.000 & 36 & & & \\
\hline & Corrected Total & 51778.556 & 35 & & & \\
\hline \multirow{7}{*}{ 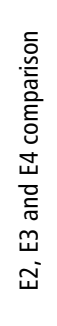 } & Corrected Model & 982321.704 & 17 & 57783.630 & 447.165 & $.000^{*}$ \\
\hline & Density & 129396.037 & 2 & 64698.019 & 500.673 & $.000^{*}$ \\
\hline & Type & 567535.481 & 5 & 113507.096 & 878.387 & $.000^{*}$ \\
\hline & Density * Type & 285390.185 & 10 & 28539.019 & 220.852 & $.000^{*}$ \\
\hline & Error & 4652.000 & 36 & 129.222 & & \\
\hline & Total & 1368670.000 & 54 & & & \\
\hline & Corrected Total & 986973.704 & 53 & & & \\
\hline
\end{tabular}

*Significant at $\mathrm{P}<0.01$ level.

indicated that the interaction (Density $\mathrm{x}$ Type) effects were also significant.

Among the materials used for spat collection, those made with synthetic materials gave better settlement than those with natural materials. This may be due to the rough and corrugated nature of synthetic surfaces than other collectors and also due to the higher surface area in the garden shade spiral. These are known to provide better tactile stimuli to setting pediveliger larvae and the crawling spats and support physical retention of larvae due to their roughness, shape and rugosity (Alagarswami et al., 1987; Friedman and Bell 1996; Taylor et al., 1998; Haws and Ellis 2000; Su et al., 2007). Ehteshami et al., (2011) reported that split roughened polyethylene pipes placed horizontally in hatchery tank bottom with $P$. margaritifera pediveligers were better for capturing spat than plastic baskets. The same authors also observed better spat settlement at the bottom of the tank rather than at the surface due to avoidance of light by the larvae. In the present study, since the tanks were covered with black cloth preventing the entry of light, spat settlement was uniform at the surface and bottom of spat collectors.

Apart from larval density and stage of larvae, the spat settlement was also found to be influenced by the colour of cultch materials. The study also revealed that the blacklip pearl oyster spat shows more affinity to black surface of the garden shade spiral. The percentage of settlement in different coloured spat collectors showed the following preference black $>$ blue $>$ yellow $>$ green $>$ brown $>$ red. This observation was incidental and not on the basis of a planned experiment. Similar observation was made by Alagarswami et. al. (1987) in hatchery rearing of $P$. fucata. They observed more settlement on the surface of black coloured tank than on the blue and white coloured ones. In the Pacific Islands, P. margaritifera larvae were observed to prefer dark surfaces for settlement with black or dark blue spat collectors producing the best yields (Coeroli et al., 1984; Sims 1994; Braley and Munro 1997). The preference for black coloured artificial collectors has been observed in spat settlement in the tanks as well as from wild for $P$. margaritifera spats (Friedman and Bell 1996; Braley and Munro 1997). The settlement of larvae of P. martensii in four different colour substrata (plastic sheets) was compared and it was observed that dark colour attracted significantly more larvae than light colour (Su et al., 2007). Similarly in P. mazatlanica, Saucedo et al., (2005) noticed that colour combination significantly influenced spat collection in hatchery.

The study clearly indicated that the ideal time for deployment of spat collectors in the hatchery is when the pediveligers are beginning to appear in the larval rearing tank. In similar larval stocking densities, the settlement was more on the spat collectors which were deployed when the larvae had not metamorphosed to spat. The study showed that more spat collection of $P$. margaritifera can be achieved in hatcheries by providing darkness and providing dark coloured, rough surfaced, corrugated and conditioned spat collectors such as the garden shade spiral at higher larval densities. 


\section{Acknowledgements}

The authors are thankful to the Director, CMFRI, Kochi for facilities. They are grateful to the Ministry of Earth Sciences, New Delhi and CMLRE, Kochi for funding a project on blacklip pearl oyster farming with which this work was carried out.

\section{References}

Alagarswami, K., S. Dharmaraj, T. S. Velayudhan and A. Chellam. 1987. Hatchery technology for pearl oyster production. In: K. Alagarswami, (Ed). Pearl Culture. Bull. Cent. Mar. Fish. Res. Inst., 39: 62- 71.

Alagarswami, K., S. Dharmaraj, A. Chellam and T. S. Velayudhan. 1989. Larval and juvenile rearing of blacklip pearl oyster Pinctada margaritifera Linnaeus. Aquaculture, 76: 43- 56.

Braley, R.D. and D. Munro. 1997. Preference for spat collector materials in tanks by larvae of Pinctada margaritifera at Penrhyn Atoll, Cook Islands. SPC Pearl Oyster Bulletin, 10: 8- 11.

Coeroli, M., D. De Gaillande, J. P. Landret and D. Coatanea. 1984. Recent innovations in cultivation of molluscs in French Polynesia. Aquaculture, 39: 45- 67.

Crossland, C. 1957. The cultivation of the mother of pearl oyster in the Red Sea. Aus. J. Mar. Freshw. Res., 8: 111- 130.

Ehteshami, F, A. Christianus, H. Rameshi, S. A. Harmin, C. R. Saad and E. Abdolalian. 2011. Evaluation of selected substrates for collection of hatchery reared black-lip pearl oyster (Pinctada margaritifera) spat. Iranian J. Fish. Sci., 10 (2): 198- 207.

Friedman, K.J. and J.D. Bell. 1996. Effects of different substrata and protective mesh bags on collection of spat of the pearl oysters, Pinctada margaritifera and Pinctada maculata. J. shellfish Res., 15: 535- 541.
Friedman, K.J., J.D. Bell and G. Tiroba. 1998. Availability of wild spat of the blacklip pearl oyster, Pinctada margaritifera from open reef systems in Solomon Islands. Aquaculture, 167: 283- 299.

Haws, M. and S.C. Ellis. 2000. Collecting blacklip pearl oyster spat. CTSA Aquafarmer Information Sheet, 144: 1- 8.

Mohamed, K. S., V. Kripa, C. Linoy Libini, K. Shanmugam, K. Prakash Rao and T.S. Velayudhan. 2010. Hatchery production of blacklip pearl oyster spat in the Andaman and Nicobar Islands- A success story. Fish. Chimes, 30 (2): 40- 41.

Passfield, R. 1989. Basic requirements to set up a small pearl farm. South pacific Commission Library, Noumea, New Caledonia. 2pp.

Rahma, I. H. and G. F. Newkrik. 1987. Economics of tray culture of the mother of pearl shell Pinctada margaritifera in the Red Sea, Sudan. J. World Aquac. Soc., 2: 156- 161.

Saucedo, P., E. H. Bervera-León, M. Monteforte, P. C. Southgate and P. MonsalvoSpencer. 2005. Factors influencing recruitment of hatchery reared pearl oyster (Pinctada mazatlanica) spat. J. Shellfish Res., 24 (1): 215- 219.

Sims, N. A. 1994. Growth of wild and cultured blacklip pearl oysters, Pinctada margaritifera Pteriidae, Bivalvia, in the Cook Islands. Aquaculture, 122: 181- 191.

Southgate, P. C. 2008. Pearl oyster culture. In : Southgate, P. C. and J. S. Lucas, (Eds.) The pearl oyster. Chapter 7. Elsevier publication, Amsterdam, Netherlands. p. 230- 272.

Su, Z., H. Liangmin, Y. Yan and H. Li. 2007. The effect of different substrates on pearl oyster Pinctada martensii (Dunker) larvae settlement. Aquaculture, 271: 377- 383.

Taylor, J. J., P. C. Southgate and R. A. Rose. 1998. Assessment of artificial substrates for collection of hatchery-reared silver-lip pearl oyster (Pinctada maxima, Jameson) spat. Aquaculture, 162: 219- 230.

Vakily, J. M. 1989. The biology and culture of mussels of the genus Perna. ICLARM Stud. Rev., 17: 63. 